\title{
The Relationship Between Responsible Tourism Practice, Destination Sustainability and Quality of Life: Perspective of Marine National Park Communities
}

\author{
Thanin Sangkhaduang ${ }^{1 *}$, Parichart Visuthismajarn ${ }^{1}$, Noodchanath Kongchouy ${ }^{2}$ \\ ${ }^{1}$ Faculty of Environmental Management, Prince of Songkla University, Hatyai, Songkhla 90110, Thailand \\ ${ }^{2}$ Faculty of Science, Prince of Songkla University, Hatyai, Songkhla 90110, Thailand
}

Corresponding Author Email: tanin.s@rmutsv.ac.th

https://doi.org/10.18280/ijsdp.160510

Received: 19 June 2021

Accepted: 3 September 2021

\section{Keywords:}

destination sustainability, ecotourism, host communities' perceptions, quality of life, responsible tourism practice

\begin{abstract}
An ideal responsible tourism practice has become the most significant role and principle for modern sustainable tourism development concept. Responsible tourism practice promotes better for tourists visit and enhances the quality of life of host communities in the destination by encouraging ethical consumption and production in all stakeholders. This paper attempted to determine the impact of host communities' perceived responsible tourism practice on perceived destination sustainability and their quality of life as well as the impact of host communities' perceived destination sustainability on perceived quality of life. The study was conducted with 355 participants from host communities in Haad Chao Mai Marine National Park, Thailand. Self-administered questionnaires were used to collect the data. The collected data were analyzed by using structural equation modeling (SEM). The results revealed that perceived responsible tourism practice had a significant impact on perceived destination sustainability and perceived quality of life. Additionally, perceived destination sustainability influenced perceived quality of life. As such, embedding responsible tourism practice in destination development plan can enable destination sustainability and better quality of life of host communities and it might make the park successful ecotourism destination.
\end{abstract}

\section{INTRODUCTION}

In Thailand, the main goals of marine national parks are to protect and conserve the ecosystems and the biological diversity. The marine national parks are also used as locations for tourism where tourism has been playing an important role in alleviating poverty and boosting economies of coastal communities all over the place [1].

Haad Chao Mai Marine National Park has been established since 1982 and has covered approximately 230.87 sq. kms. along the coastline on the Andaman Sea in Trang Province. It is famous for tourist attraction as there is $20-\mathrm{km}$ beautiful and peaceful sandy beach with lines of pine trees. Several small islands of the national park, i.e., Koh Kradan, Koh Cheuk, Koh Mook and Koh Waen, are well-known for their beautiful shallow coral reefs and are an ideal destination for natural tourism and recreation, especially for snorkeling.

The largest population of dugong in Thailand can be found in Li Bong Island, Haad Chao Mai Marine National Park, which is the biggest area of seagrass - a major food source of dugong. According to the Convention on Ramsar Site No. 1182 entitled "Haad Chao Mai's Ramsar Site-Li Bong Archipelago Wildlife Territory-Trang Estuary", some areas of Haad Chao Mai Marine National Park are classified as Ramsar sites as they have high level of biodiversity and complete ecosystem and serves as a habitat for marine creatures [2]. Consequently, Trang Province is assigned as an ecotourism destination by the Office of Strategy Management for Southern Province Cluster, local governance agency that responsible for expanding and supporting tourism development [3].

The sustainable tourism development has drawn attention to and been established as a policy approach by several relevant agencies around the world. Tourism destination management was employed to indicate sustainable tourism [4]. Economic, social, and environmental aspects were used as a framework to evaluate sustainable tourism in various destinations [5].

However, the tourism industry still faces sustainability challenges. There are various arguments on the effectiveness of sustainable policy in managing tourism development as it is based on the interactions between people and tourist destinations which is notably sensitive to social and physical conditions of destination environment. Hence, responsible tourism practice was introduced and embedded in destination management plan to support sustainable tourism development [6-8].

Responsible tourism has attracted significant attention to both in practice and academic research in the tourism domain [9]. It refers to principles and practices of tourism development that intended to create more appropriate place of living for host communities and of travelling for tourists to by encouraging ethical consumption and production in all stakeholders [10]. Stakeholders in tourist destinations mainly include government, tourism businesses, tourists, and host communities. The host communities play a pivotal role as a primary stakeholder which are affected by the tourism operations [11]. The involvement of host communities is particularly crucial to successful implementation of responsible tourism, therefore, some researchers studied on responsible tourism regarding the perspectives of host 
communities.

In 2019, Gong et al. [12] studied the impact of responsible tourism practice of host communities in Bangkok, Thailand and found that destination sustainability was risen due to responsible tourism practice. In 2017, Mathew and Sreejesh [13] investigated perceptions of host communities in different tourism destinations in India and concluded that responsible tourism practice initiatives created conditions for destination sustainability and improved the host communities' quality of life. In addition, Hanafiah et al. [7] explored perceptions of Langkawi Island communities in 2016 and revealed that responsible tourism practice had an influence on perceived better quality of life.

There are very few studies investigating host communities' perception on responsible tourism practice in Thailand and empirical study on the impact of responsible tourism practices on destination sustainability and quality of life regarding the perspective of host communities living around marine national parks have not been investigated. As such, this study aims to achieve a better understanding on the levels and the links of responsible tourism practice, destination sustainability, and quality of life regarding host communities' perspective in Haad Chao Mai Marine National Park, Thailand.

\section{LITERATURE REVIEW}

\subsection{Ecotourism, sustainable tourism, and responsible tourism practice}

Ecotourism is tourism focused on enhancing or maintaining natural systems through tourism and developing economic and social of host communities, which has similar objectives as sustainable tourism [14]. It also enables sustainable livelihood of host communities [15]. Additionally, some scholars indicated that ecotourism has been defined as a component of sustainable tourism (e.g., $[15,16])$.

Responsible tourism had gained significant attention over the past few decades and had been adopted in numerous tourist destinations [13, 17]. Responsible tourism was considered as a strategic management or a significant instrument embraced in tourism destination to minimize negative impacts on economic, social, and environment as well as maximize positive impacts on tourism development [6-10, 12, 13, 17-19]. It built on the same grounds as sustainable tourism with overlapping essential goal that was to enable sustainability in current tourism situation and not to stop developing tourism in future generation $[10,17,19]$.

According to an extensive literature review on tourism, responsible tourism practice had been defined in several ways by several researchers.

Chan and Xin [6] defined responsible tourism practice more on the responsibility to reinforce tourist experiences and to create a better destination awareness.

Mihalic [8] referred responsible tourism practice to the actual behavior that made real tourism more sustainability and linked responsible tourism to responsible behavior with the sustainable tourism concept.

Gong et al. [12] indicated that responsible tourism practice was a direct attention on ethical behaviors or actions taken by tourism stakeholders, possibly educated by tourism principles, and was able to characterize either individuals or organizations including host communities, tourism businesses, government agencies, and tourists
From the definition given by the scholars above, this paper defines responsible tourism practice as an ethical behavior of tourism stakeholders that made destination sustainable.

As reported by Koshy et al. [20], responsible tourism practice was based on the concept of 'the triple bottom line' which equally emphasized on three tiers of sustainability, i.e., economy, social and environment. This concept was also in line with the sense of sustainable development. Goodwin [21] proposed three principles as key guidelines of responsible tourism practices: economy, social and environment. Principle on economic aspect included maximizing local economic benefits, adopting equitable business practices, providing appropriate and sufficient support to small, medium and micro enterprises, etc. For social aspect, it was indicated to ensure that tourism is access for all, encourage social and host cultural diversity, ensure that tourism improve health and education. In term of environment, it was advised to use resources sustainably, reduce waste and over consumption, respect the integrity of vulnerable ecosystems and protected areas, promote education and awareness for sustainable development for all stakeholders, etc. Apart from the above three dimensions of responsible tourism, some scholars proposed four dimensions for measuring responsible tourism practice which were economic, social, culture, and environment [13, $20]$.

\subsection{Responsible tourism practice and destination sustainability}

A study of responsible behavior on community-based tourists revealed that responsible tourism practice could induce tourism and improve tourist destinations, thus, fostering responsible behavior seemed be the best practice for sustainable tourism [22]. Pirlone and Spadaro [19] pointed out that responsible tourism practice was an expression of preserving environment, culture and local traditions and participation and active involvement of people aiming to create sustainable tourism. Moreover, several scholars asserted that responsible tourism practice had played an essential role for destination sustainability (e.g., [6, 12, 13, 19, 20]). Tourist destinations were basically communities of certain stakeholders who were affected by the tourism operations. Therefore, sustainable tourist destinations were unable to be achieved without considering host communities' perceptions on tourism impacts [11]. Some researchers investigated host communities' perceptions to measure destination sustainability, for example, Lee and Jan [23] employed host communities' perceptions on destination sustainability as strategies to develop tourism plan. In addition, several researchers used host communities' perceptions on responsible tourism practice as an indicator to examine destination sustainability (e.g., $[12,13])$. Based on the above argument, the hypothesis was proposed as:

H1: Host communities' perceived responsible tourism practice has a positive impact on their perceived destination sustainability.

\subsection{Destination sustainability and quality of life}

Quality of life referred to individual's satisfaction with life and individual's feelings of well-being or fulfillment with their experience. It depended on individual opinion and feeling which might be perceived differently by different people [24]. Klein [25] stated that the best indicator of quality of life in 
tourism destination was host communities, all walks of life, and all segments of society in and around. According to Kim [26], quality of life was categorized in four dimensions which included (1) Material well-being: consisted of satisfaction with cost of living, income and employment, (2) Community wellbeing: consisted of satisfaction with community life and setting that make up people's appreciation with the greater than neighborhood area where they live, (3) Emotional wellbeing: consisted of satisfaction with leisure well-being and spiritual well-being, and (4) Health and safety well-being: consisted of satisfaction with health well-being and safety well-being.

Studies on quality of life investigated whether social environmental factors increased or diminished quality of life of people and engaged an assessment of quality of life in two dimensions of perception: better or worse [27]. Jeon, Kang and Desmarais [28] studied on host communities' perceived quality of life in tourist destination and found that there was relationship existed between host communities' perceived environment sustainability and their perceived quality of life. According to the above argument, the hypothesis was proposed as:

H2: Host communities' perceived destination sustainability has a positive impact on their perceived quality of life.

\subsection{Responsible tourism practice and quality of life}

As suggested by Andereck and Nyaupane [24], the host communities who perceive higher degrees of their own personal gained from tourism had more positive attitudes toward tourism and provided more supports on tourism development. Liao et al. [29] indicated that quality of life had a positive relationship with host communities' perceived benefits of tourism development. Thus, if host communities felt secure on their quality of life, they tended to support tourism development than those who did not feel they acquired tourism's benefit. In other words, if perceived quality of life was lower, host communities might be unwilling to support tourism activities in their community [18]. Therefore, attitudes and perceptions of host communities should directly report to tourism administration because they were crucial information for improving well-being of destination communities and reducing costs of tourism development [30].

Previous studies suggested that responsible tourism practice might contribute new skills and improve accessibility to education, health care, clean water, transportation network and so on. Furthermore, it was able to enhance the quality of life of the destination communities [6, 20]. Hanafiah et al. [7] asserted that responsible tourism practice could minimize negative consequences of tourism development. Additionally, host communities' perceptions on responsible tourism practice had strong relationship and direct influence on their quality of life. Regarding to the above argument, the hypothesis was proposed as:

H3: Host communities' perceived responsible tourism practice has a positive impact on their perceived quality of life.

\subsection{Conceptual framework}

As discussed, this paper developed a conceptual framework of the relationship between responsible tourism practice, destination sustainability and quality of life. This explained that perceived responsible tourism practice has a positive impact on perceived destination sustainability and positive impact on perceived quality of life. Additionally, perceived destination sustainability positively influences percieved quality of life. The relationship between the variables are clarified by conceptual model and research hypotheses as showed in Figure 1.

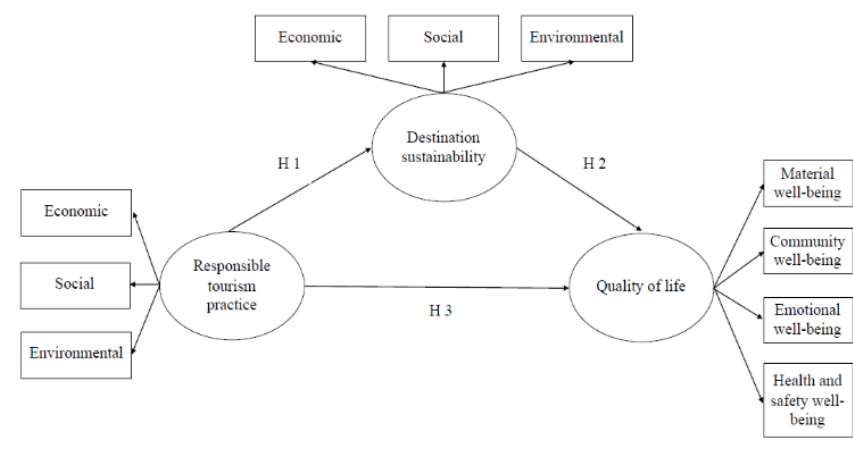

Figure 1. Conceptual model and hypotheses

\section{METHODOLOGY}

To address the research objectives and examine hypothesized relationships, a quantitative research approach was employed this study. Self-administered questionnaire was designed to gather information for two months from November to December 2019. The quota sampling method was used to select 355 respondents from total of approximately 3,200 household in six villages located within Haad Chao Mai Marine National Park including Ban Pak Meng, Ban Chang Lang, Ban Koh Mook, Ban Khuan Tung Ku, Ban Nam Rab and Ban Haad Yao based on the population size of each community.

\subsection{Instrument}

The questionnaire consisted of four parts. The first part included questions regarding respondents' demographic profile and the other three parts were designed to explore host communities' perceptions concerning responsible tourism practice, destination sustainability, and quality of life which required respondents to respond on five-point Likert scales (1 $=$ strongly disagree to $5=$ strongly agree). The perceptions on responsible tourism practice were measured by ten items consisting of three dimensions: economic responsibility, social responsibility and environmental responsibility. These items were adapted from Hanafiah et al. [7], Mathew and Sreejesh [13] and Hafiz et al. [18]. The perceptions on destination sustainability were measured by ten items including three dimensions: economic sustainability, social sustainability and environmental sustainability. They were adapted from Mathew and Sreejesh [13], Lee and Jan [23] and Mearns [31]. Finally, perceptions on quality of life were measured by twelve items consisting of four dimensions: material well-being, community well-being, emotional wellbeing, and health and safety well-being. They were adapted from Mathew and Sreejesh [13] and Kim et al. [32].

The questionnaire was reviewed by academicians to verify the correctness of content and formulation of items. A pilot test survey was conducted with 30 respondents from host communities at Ban Toong Yipeng, Koh Lanta, Krabi Province. The questionnaire items on the responsible tourism 
practice, the destination sustainability and the quality of life were subjected to reliability analysis indicating a Cronbach's alpha coefficient of $0.84,0.88$, and 0.88 , respectively.

\subsection{Data analysis}

Data on demographic profile was analyzed using percentage. Data on perceptions of host communities were screened to check missing values and outliers and it was found that the entire dataset did not comprise of missing values and outliers. To determine the data distribution, the univariate normality was investigated by examining skewness and kurtosis of the study items. The result of skewness ranged from -0.76 to -0.18 and kurtosis ranged from -0.54 to 0.39 . The acceptable value of skewness was less than 3 and of kurtosis was less than 10 [33]. These suggested that there were no major issues with regard to the normality distribution.

\section{RESULTS}

\subsection{Respondents' demographic profile}

Respondents' demographic profile was analyzed and presented in Table $1.57 .70 \%$ of respondents were female.
$44.3 \%$ aged between 31 to $50.56 .10 \%$ of them were graduated from primary school. Approximately $70 \%$ have been residing in this area for 11 years or more. With respect to income, about $64.50 \%$ earned 15,000 Bath or less. $73.50 \%$ of respondents' careers were irrelevant to tourism.

Table 1. Respondents' demographic profile

\begin{tabular}{ccc}
\hline Demographic & Category & Percentages \\
\hline Gender & Male & 42.30 \\
& Female & 57.70 \\
Age & $18-30$ & 31.3 \\
& $31-50$ & 44.3 \\
& 51 and older & 24.60 \\
Education & Primary school & 56.10 \\
& Secondary & 25.40 \\
& school/Vocational & 18.60 \\
Years of & Bachelor's degree or higher & 18.80 \\
Residency & 5 years or less & 11.50 \\
& 6-10 years & 69.60 \\
Income (Bath) & 11 years or more & 64.50 \\
& 15,000 or less & 25.40 \\
& $15,001-30,000$ & 10.10 \\
Career & 30,001 or more & 26.50 \\
& Involvement in tourism & 73.50 \\
& Non-involvement in & \\
& tourism & \\
& &
\end{tabular}

Table 2. Assessment results of the measurement model

\begin{tabular}{|c|c|c|c|c|}
\hline Constructs/ Dimension & Associated Items & Loadings & AVE & $\mathbf{C R}$ \\
\hline \multicolumn{5}{|c|}{ Responsible Tourism Practice } \\
\hline \multirow[t]{3}{*}{ Economic Responsible } & Creating employment opportunities & 0.83 & 0.64 & 0.84 \\
\hline & Purchasing of local produces & 0.81 & & \\
\hline & Encouraging local enterprise & 0.75 & & \\
\hline \multirow[t]{3}{*}{ Social Responsible } & Local communities' participation & 0.67 & 0.53 & 0.77 \\
\hline & Creating employment opportunities for backward linkages & 0.86 & & \\
\hline & Creating training and skills development & 0.64 & & \\
\hline \multirow[t]{5}{*}{ Environmental Responsible } & Environmental protection & 0.58 & 0.44 & 0.76 \\
\hline & Do not exceed the ecological carrying capacity & 0.63 & & \\
\hline & Creating waste management programs & 0.86 & & \\
\hline & Creating ecological restoration programs & 0.55 & & \\
\hline & Destination Sustainability & & & \\
\hline \multirow[t]{3}{*}{ Economic Sustainability } & Improving consistent and reliable income & 0.84 & 0.70 & 0.87 \\
\hline & Improving of living standards & 0.89 & & \\
\hline & Increasing of local enterprise & 0.77 & & \\
\hline \multirow[t]{3}{*}{ Social Sustainability } & Improving community empowerment & 0.67 & 0.57 & 0.80 \\
\hline & Improving benefits to backward people linkages & 0.83 & & \\
\hline & Increasing of facilities & 0.76 & & \\
\hline \multirow{5}{*}{ Environmental Sustainability } & Improving natural environment & 0.75 & 0.57 & 0.83 \\
\hline & Improving biodiversity & 0.85 & & \\
\hline & Without pollution & 0.51 & & \\
\hline & Improving of environmental awareness & 0.86 & & \\
\hline & Quality of Life & & & \\
\hline \multirow[t]{3}{*}{ Material Well-being } & Satisfaction with job security & 0.72 & 0.64 & 0.84 \\
\hline & Satisfaction with income & 0.89 & & \\
\hline & Satisfaction with cost of living & 0.78 & & \\
\hline \multirow[t]{3}{*}{ Community Well-being } & Satisfaction with community life & 0.77 & 0.61 & 0.82 \\
\hline & Satisfaction with community environment & 0.89 & & \\
\hline & Satisfaction with amenities and services & 0.66 & & \\
\hline \multirow[t]{3}{*}{ Emotional Well-being } & Satisfaction with influx of tourists & 0.70 & 0.57 & 0.80 \\
\hline & Satisfaction with spare time & 0.84 & & \\
\hline & Satisfaction with leisure activity & 0.72 & & \\
\hline \multirow{3}{*}{ Health and Safety Well-being } & Satisfaction with community cleanliness & 0.64 & 0.57 & 0.80 \\
\hline & Satisfaction with low levels of crime rate & 0.67 & & \\
\hline & Satisfaction with low levels of accident rate & 0.93 & & \\
\hline
\end{tabular}




\subsection{Measurement model}

Confirmatory factor analysis (CFA) was conducted to test the goodness-of-fit of the measurement model using LISREL program. It is considered to be a good model fit if the value of the chi-square to degrees of freedom ratio $\left(\chi^{2} / \mathrm{df}\right)$ is less than 3 , the goodness of fit index (GFI), adjusted goodness of fit index (AGFI), comparative fit index (CFI), and norm fit index (NFI) is higher than 0.90 , and the root mean square error of approximation (RMSEA) is less than 0.08 [34].

Measurement model on responsible tourism dimension showed $\chi 2 / \mathrm{df}=0.00, \mathrm{RMSEA}=0.00$. Similarly, measurement model on destination sustainability showed $\chi 2 / \mathrm{df}=0.00$, RMSEA $=0.00$. Additionally, measurement model on quality of life showed $\chi 2 / \mathrm{df}=1.06 / 1.00(1.06), \mathrm{GFI}=1.00, \mathrm{AGFI}=$ $0.99, \mathrm{CFI}=1.00, \mathrm{NFI}=1.00$, and $\mathrm{RMSEA}=0.01$. These CFA results indicated that the measurement model had a good fit.

Factor loadings, Average Variance Extracted (AVE) and Composite Reliability (CR) were used to assess the convergent validity of the measurement model (Table 2). The item loadings ranged from 0.51 to 0.93 were above the required level of 0.5 as recommended [35]. Additionally, nine of ten AVE constructs were greater than the suggested threshold of 0.50 , only one construct was 0.44 and the CR coefficient was also ranged from 0.76 to 0.87 . As suggested by Fornell and Larcker [36], if AVE was less than 0.5, but CR coefficient was higher than 0.6 , the convergent validity of the construct was adequate.

According to the analysis results of measurement model in latent variable (Table 3 ), the item loadings ranged from 0.61 to 0.80 were above the required level of 0.5 as recommended. AVE values ranged from 0.49 to 0.55 and the CR coefficient was ranged from 0.76 to 0.79 as recommended to establish internal consistency.

Table 3. Assessment results of the measurement model in latent variable

\begin{tabular}{|c|c|c|c|c|}
\hline $\begin{array}{l}\text { Constructs/ } \\
\text { Dimension }\end{array}$ & $\begin{array}{l}\text { Associated } \\
\text { Items }\end{array}$ & Loadings & AVE & CR \\
\hline \multirow{3}{*}{$\begin{array}{c}\text { Responsible } \\
\text { Tourism } \\
\text { Practice }\end{array}$} & $\begin{array}{c}\text { Economic } \\
\text { Responsible }\end{array}$ & 0.71 & 0.51 & 0.76 \\
\hline & $\begin{array}{c}\text { Social } \\
\text { Responsible }\end{array}$ & 0.80 & & \\
\hline & $\begin{array}{l}\text { Environmental } \\
\text { Responsible }\end{array}$ & 0.63 & & \\
\hline \multirow{3}{*}{$\begin{array}{l}\text { Destination } \\
\text { Sustainability }\end{array}$} & $\begin{array}{c}\text { Economic } \\
\text { Sustainability }\end{array}$ & 0.77 & 0.55 & 0.79 \\
\hline & $\begin{array}{c}\text { Social } \\
\text { Sustainability }\end{array}$ & 0.73 & & \\
\hline & $\begin{array}{l}\text { Environmental } \\
\text { Sustainability }\end{array}$ & 0.73 & & \\
\hline \multirow{4}{*}{ Quality of Life } & $\begin{array}{l}\text { Material Well- } \\
\text { being }\end{array}$ & 0.72 & 0.49 & 0.79 \\
\hline & $\begin{array}{l}\text { Community } \\
\text { Well-being }\end{array}$ & 0.77 & & \\
\hline & $\begin{array}{c}\text { Emotional Well- } \\
\text { being }\end{array}$ & 0.68 & & \\
\hline & $\begin{array}{l}\text { Health and } \\
\text { Safety Well- } \\
\text { being }\end{array}$ & 0.61 & & \\
\hline
\end{tabular}

\subsection{Structural model}

The structural equation model was analyzed to determine the consistency of the model with the empirical data based on the fit indices, and to test the hypothesis relationships between the variables. The overall model showed a good fit based on the recommended range by [34], $\chi 2 / \mathrm{df}=36.11 / 26(1.38)$, GFI $=0.98, \mathrm{AGFI}=0.96, \mathrm{CFI}=1.00, \mathrm{NFI}=0.99$, and $\mathrm{RMSEA}=$ 0.03 .

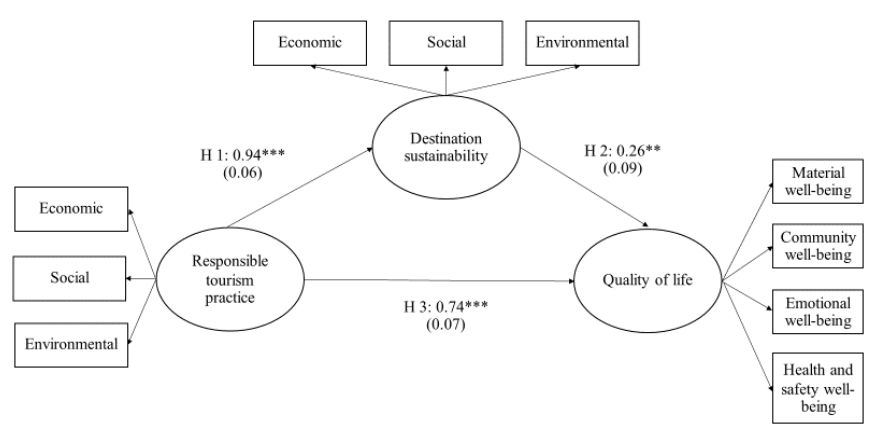

Figure 2. Structural model result

The hypothesis with the path coefficient values was then analyzed and displayed in Figure 2 and Table 4. It was found that host communities' perceptions on responsible tourism practice influenced both variables: perceived destination sustainability and perceived quality of life, respectively $(\beta=$ $0.94, \mathrm{t}=14.56, \mathrm{p}<0.001 ; \beta=0.74, \mathrm{t}=10.36, \mathrm{p}<0.001)$. Additionally, host communities' perceptions on destination sustainability indicated a positive impact on perceived quality of life $(\beta=0.26, t=2.79, p<0.01)$. Thus, hypotheses 1,2 , and 3 were all supported.

Table 4. Path coefficients and hypothesis testing

\begin{tabular}{|c|c|c|c|c|}
\hline Hypothesis/Path & Coefficient & $\mathbf{t}$ & SE & Test result \\
\hline $\begin{array}{c}\text { H1: Responsible } \\
\text { tourism practice } \\
\rightarrow \\
\text { Destination } \\
\text { sustainability }\end{array}$ & $0.94 * * *$ & 14.56 & 0.06 & Supported \\
\hline $\begin{array}{c}\text { H2: Destination } \\
\text { sustainability } \\
\rightarrow \\
\text { Quality of life }\end{array}$ & $0.26^{* *}$ & 2.79 & 0.09 & Supported \\
\hline $\begin{array}{l}\text { H3: Responsible } \\
\text { tourism practice } \\
\longrightarrow \\
\text { Quality of life }\end{array}$ & $0.74 * * *$ & 10.36 & 0.07 & Supported \\
\hline
\end{tabular}

\section{DISCUSSION}

This study fills the research gap by conducting an empirical study to examine host communities' perceived responsible tourism practice, perceived destination sustainability, and perceived their quality of life in Haad Chao Mai Marine National Park, Thailand. It also investigated the relationships among the mentioned predictors.

The first hypothesis expected relationship between the host communities' perceived responsible tourism practice and perceived destination sustainability was supported from data analysis. The perceived responsible tourism practice issue had a significant direct influence on perceived destination sustainability. The finding indicated that host communities' 
perception concerning responsible tourism practice was an essential predictor to determine their perceptions of destination sustainability. The second hypothesis expected relationship between the host communities' perceived destination sustainability and perceived their quality of life was supported. The perceived destination sustainability issues had a significant direct influence on perceived quality of life. The results suggested that economic, social and environmental dimensions of the destination sustainability were very crucial to deliver perceived quality of life among host communities. Host communities who perceived aspects of destination sustainability were then more likely to perceive their quality of life. Additionally, the last hypothesis of the study expected relationship between the host communities' perceived responsible tourism practice and perceived their quality of life was supported. The perceived responsible tourism practice issue had a significant influence on perceived quality of life. It was found that perceived responsible tourism practices of host communities were a predictor of their quality of life. The above results were in accordance with previous studies that there was significant relationship between responsible tourism practice and destination sustainability [13], between destination sustainability and quality of life [13] and, between responsible tourism practice and quality of life [7].

\section{CONCLUSION}

This study contributes to knowledge and understanding of the responsible tourism practice and its positive impacts on destination sustainability and quality of life. It has crucial implications for academic and administrative work in tourism context.

On the basis of the results, responsible tourism practice could be used as a key consideration in tourism-related policy identification and management as the inclusion of economic, social and environmental aspects in tourism projects and policies are able to develop more responsible practice, especially in tourism business sector [37]. Relevant government agencies should encourage tourism stakeholders to have ethical behaviors to make sustainability of the destination. As a result, responsible tourism practice might contribute essentially to the process of tourism strategic planning for the Office of Strategy Management for Southern Province Cluster (OSM Andaman) to enable Trang province a complete ecotourism destination.

However, there are some limitations that might be considered in future research. This study focused on single group of stakeholders which was the host community. Future study on other stakeholders' perceptions such as tourism businesses, government agencies, and tourist might be investigated. In addition, the study only involved host communities from Haad Chao Mai Marine National Park, Trang province. More studies with other communities in Trang province should then be implemented.

\section{REFERENCES}

[1] Roman, G.S.R., Dearden, P., Rollins, R. (2007). Application of zoning and "limits of acceptable change" to manage snorkelling tourism. Environ Manage, 39: 819-830. https://doi.org/10.1007/s00267-006-0145-6

[2] Office of Natural Resources and Environmental Policy and Planning. (2004). Biodiversity In wetland, Hat Chao Mai National Park-Libong Island Hunting Area-Pak Nam Trang, Trang Province. Ministry of Natural Resources and Environment, Thailand.

[3] The Office of Strategy Management for Southern Province Cluster (OSM Andaman). (2017). Planning of southern province group on Andaman Coast (Ranong, PhangNga, Phuket, Krabi and Trang) 2018-2021 (Revised ed.). OSM Andaman, Thailand.

[4] Huang, Y., Coelho, V.R. (2017). Sustainability performance assessment focusing on coral reef protection by the tourism industry in the Coral Triangle region. Tourism Management, 59: 510-527. https://doi.org/10.1016/j.tourman.2016.09.008

[5] Mikulic, J., Kozic, I., Kresic, D. (2015). Weighting indicators of tourism sustainability: A critical note. Ecological Indicators, 48: 312-314. http://doi.org/10.1016/j.ecolind.2014.08.026

[6] Chan, J.K.L., Xin, T.K. (2015). Exploring definitions and practices of responsible tourism in Kinabalu National Park, Sabah, Malaysia. Journal of Tourism and Hospitality Management, 3(5-6): 87-101. http://doi.org/10.17265/2328-2169/2015.06.001

[7] Hanafiah, M.H., Azman, I., Jamaluddin, M.R., Aminuddin, N. (2016). Responsible tourism practices and quality of life: Perspective of Langkawi Island communities. Procedia-Social and Behavioral Sciences, 222:

406-413.

https://doi.org/10.1016/j.sbspro.2016.05.194

[8] Mihalic, T. (2016). Sustainable-responsible tourism discourse-towards 'responsustable' tourism. Journal of Cleaner Production, 111: 461-470. https://doi.org/10.1016/j.jclepro.2014.12.062

[9] Caruana, R., Glozer, S., Crane, A., McCabe, S. (2014). Tourists' accounts of responsible tourism. Annals of Tourism Research, 46: 115-129. http://dx.doi.org/10.1016/j.annals.2014.03.006

[10] Saarinen, J. (2014). Critical sustainability: Setting the limits to growth and responsibility in tourism. Sustainability, $6(1)$ : http://doi.org/10.3390/su6010001

[11] Safshekan, S., Ozturen, A., Ghaedi, A. (2020). Residents environmentally responsible behavior: An insight into sustainable destination development. Asia Pacific Journal of Tourism Research, 25(4): 409-423. https://doi.org/10.1080/10941665.2020.1737159

[12] Gong, J., Detchkhajornjaroensri, P., Knight, D.W. (2019). Responsible tourism in Bangkok, Thailand: Resident perceptions of Chinese tourist behaviour. International Journal of Tourism Research, 21(2): 221-233. https://doi.org/10.1002/jtr.2256

[13] Mathew, P.V., Sreejesh, H. (2017). Impact of responsible tourism on destination sustainability and quality of life of community in tourism destinations. Journal of Hospitality and Tourism Management, 31: 83-89. http://doi.org/10.1016/j.jhtm.2016.10.001

[14] Jaini, N., Anuar, A.N.A., Daim, M.S. (2012). The practice of sustainable tourism in ecotourism sites among ecotourism providers. Asian Social Science, 8(4): 175179. https://doi.org/10.5539/ass.v8n4p175

[15] Kiper, T. (2013). Role of ecotourism in sustainable development. Advances in Landscape Architecture, pp. 773-802. http://doi.org/10.5772/55749

[16] Bansal, S.P., Kumar, J. (2011). Ecotourism for 
community development: A stakeholder's perspective in Great Himalayan National Park. International Journal of Social Ecology and Sustainable Development, 2(2): 3140. https://doi.org/10.4018/jsesd.2011040103

[17] Tichaawa, T.M., Samhere, S. (2015). Responsible tourism: Analysing implementation and challenges in East London using the stakeholder approach. African Journal for Physical Health Education, Recreation and Dance, 21(1.2): 401-414. https://hdl.handle.net/10520/EJC172399

[18] Hafiz, M., Jamaluddin, M., Zulkifly, M., Othman, N. (2014). Exploring responsible tourism development facet. Theory and Practice in Hospitality and Tourism Research, pp. 173-177. https://doi.org/10.1201/b17390-35

[19] Pirlone, F., Spadaro, I. (2017). Sustainable tourism action plan in the Mediterranean coastal areas. International Journal of Sustainable Development and Planning, 12(6): 995-1005. https://doi.org/10.2495/SDPV12-N6-995-1005

[20] Koshy, M.P., Kuriakose, V., Mathew, P. (2016). Measurement for responsible tourism: Development of a stakeholder-based scale. South Asian Journal of Tourism and Heritage, 9(1): 132-152. https://doi.org/10.5958/2321-5763.2018.00075.6

[21] Goodwin, H. (2014). Cape Town Declaration on Responsible Tourism. https://responsibletourismpartnership.org/cape-towndeclaration-on-responsible-tourism.

[22] Lee, T.H., Jan, F.H, Yang, C.C. (2013). Conceptualizing and measuring environmentally responsible behaviors from the perspective of community-based tourists. Tourism Management, 36: 454-468. https://doi.org/10.1016/j.tourman.2012.09.012

[23] Lee, T.H., Jan, F.H. (2019). Can community-based tourism contribute to sustainable development? Evidence from residents' perceptions of the sustainability. Tourism Management, 70: 368-380. https://doi.org/10.1016/j.tourman.2018.09.003

[24] Andereck, K.L., Nyaupane, G.P. (2011). Exploring the nature of tourism and quality of life perceptions among residents. Journal of Travel Research, 50(3): 248-260. https://doi.org/10.1177/0047287510362918

[25] Klein, R.A. (2011). Responsible cruise tourism: Issues of cruise tourism and sustainability. Journal of Hospitality and Tourism Management, 18(1): 107-116. https://doi.org/10.1375/jhtm.18.1.107

[26] Kim, K. (2002). The effects of tourism impacts upon quality of life residents in the community, Virginia Polytechnic Institute and State University, Blacksburg,
Virginia. https://doi. org/etd-12062002-123337

[27] Suntikul, W., Pratt, S., Kuan, W.I., Wong, C.I., Chan, C.C., Choi, W.L., Chong, O.F. (2016). Impacts of tourism on the quality of life of local residents in Hue, Vietnam. An International Journal of Tourism and Hospitality Research, 27(4): 405-420. http://dx.doi.org/10.1080/13032917.2016.1138234

[28] Jeon, M.M., Kang, M.M., Desmarais, E. (2016). Residents' perceived quality of life in a cultural-heritage tourism destination. Applied Research in Quality of Life, 11(1): 105-123. http://doi.org/10.1007/s11482-0149357-8

[29] Liao, X.Y., So, S.I., Lam, D. (2016). Residents' perceptions of the role of leisure satisfaction and quality of life in overall tourism development: Case of a fastgrowing tourism destination-Macao. Asia Pacific Journal of Tourism Research, 21(10): 1100-1113. http://doi.org/10.1080/10941665.2015.1107111

[30] Sharpley, R. (2014). Host perceptions of tourism: A review of the research. Tourism Management, 42: 37-49. http://doi.org/10.1016/j.tourman.2013.10.007

[31] Mearns, K.F. (2011). Using sustainable tourism indicators to measure the sustainability of a communitybased ecotourism venture: Malealea Lodge Pony Trek Centre, Lesotho. Tourism Review International, 15: 135147. https://doi.org/10.3727/154427211X13139345020499

[32] Kim, K., Uysal, M., Sirgy, M.J. (2013). How does tourism in a community impact the quality of life of community residents? Tourism Management, 36: 527540. https://doi.org/10.1016/j.tourman.2012.09.005

[33] Kline, R.B. (2015). Principles and Practice of Structural Equation Modeling. Guilford Publications.

[34] Hu, L.T., Bentler, P.M. (1999). Cutoff criteria for fit indexes in covariance structure analysis: Conventional criteria versus new alternatives. Structural Equation Modeling: A Multidisciplinary Journal, 6(1): 1-55. https://doi.org/10.1080/10705519909540118

[35] Hair, J.F., Black, W.C., Babin, B.J., Anderson, R.E. (2010). Multivariate Data Analysis. Prentice-Hall.

[36] Fornell, C., Larcker, D.F. (1981). Evaluating structural equation models with unobservable variables and measurement error. Journal of Marketing Research, 18(1): 39-50. https://doi.org/10.2307/3151312

[37] Candia, C., Pirlone, F., Spadaro, I. (2020). Integrating the carrying capacity methodology into tourism strategic plans: A sustainable approach to tourism. International Journal of Sustainable Development and Planning, 15(3): 93-401. https://doi.org/10.18280/ijsdp.150317 